\title{
Bacterial contamination of amniotic membrane
}

\author{
Philip J Adds, Charles Hunt, Stephen Hartley
}

Department of

Biomedical Sciences,

Queen Mary Westfield

College, London

E1 4NS, UK

P J Adds

NBS Tissue Services London and SE, East Anglia Tissue Bank,

Cambridge CB2 2PT C Hunt

National Blood Service, Department of Bacteriology, London NW9 5BG S Hartley

Correspondence to: Philip Adds, The Medical College of St Bartholomew's and the Royal London, Department of Biomedical Sciences, Queen Mary Westfield College, Mile End, London E1 4NS, UK p.j.adds@qmw.ac.uk

Accepted for publication 23 August 2000

Table 1 Different bacterial species identified on each sample

\begin{abstract}
Aim-In the light of interest being shown in amniotic membrane grafts for use in ocular surgery, this study aims to identify the bacterial contaminants commonly found on placental membranes from both caesarean and vaginal deliveries.

Methods-Samples of placental membrane were taken following both elective caesarean and normal vaginal deliveries. Bacterial contaminants were identified. Results-All samples were contaminated. A greater number of different species were recovered from the vaginal deliveries, including several which were actually or potentially pathogenic.

Conclusion-There is a greater risk of contamination from pathogenic bacteria on placentas from vaginal deliveries. It is recommended that amnion for use in ocular surface procedures should be retrieved only from placentas following elective caesarean deliveries.

(Br f Ophthalmol 2001;85:228-230)
\end{abstract}

Amniotic membrane has been used sporadically since $1910^{1}$ in a variety of clinical applications, including intra-abdominal and reconstructive surgery, and as a dressing for burns and chronic ulcers. ${ }^{2-6}$ Persistent corneal epithelial defects with ulceration have been effectively managed by covering with a layer of preserved human amnion. The basement membrane of the amnion facilitates migration of epithelial cells, reinforces adhesion, and promotes epithelial differentiation. ${ }^{7-11}$ Application of amniotic membrane may also prevent or reduce the

\begin{tabular}{|c|c|c|c|c|c|c|c|c|c|c|c|}
\hline \multirow[b]{2}{*}{ Organism identified } & \multicolumn{11}{|c|}{ Placenta sample number } \\
\hline & 1 & 2 & 3 & 4 & 5 & 6 & 7 & 8 & 9 & 10 & 11 \\
\hline Bacillus sp & & & & & & & $\square$ & & & & \\
\hline Bacteroides fragilis & & घ & & & & & & & & & \\
\hline Bacteroides vulgatus & & & & & & - & & & & & \\
\hline Bifidobacterium adolescentis & & & & & & & & घ & & & \\
\hline Bifidobacterium sp & & & घ & & & & & & & & \\
\hline Diphtheroid & $\square$ व & $\square$ घ & & ! & $\square$ & $\mathbf{\square}$ & & & घ & - & $\square$ \\
\hline Enterococcus faecalis & & & $\square$ & & घ & & - & & & & \\
\hline Escherichia coli & & & & & & & & घ & घ & & \\
\hline Lactobacillus sp & & & - & & & & & & & & \\
\hline Micrococcus kristinae & & & & 口 & & & & & & & \\
\hline $\begin{array}{l}\text { Propionibacterium acnes } \\
\text { Propionibacterium avidum }\end{array}$ & $\square$ घ & $\square$ & $\square$ - & & $\square$ & & $\square$ & $\square$ & $\square$ & $\square$ ( & $\square$ \\
\hline Shigella sp & & & & & घ & & & & & & \\
\hline Staph aureus & & & & & & & घ & & & & \\
\hline Staph epidermidis & $\square$ व & - & & $\square$ & $\square$ ( & & & ! & $\square$ (⿴囗十 & & $\square$ \\
\hline Staph haemolyticus & & & & & & & $\square$ & & m & & \\
\hline Staph intermedius & & & $\square$ & & & & & - & & & \\
\hline Staph lugdunensis & & & घ & & & $\square$ & & & & & \\
\hline Strep agalactiae & & & & & & - & & & & & \\
\hline Strep constellatus & & & & & & & & & & a & \\
\hline Strep gordonii & & & & & & $\square$ & & & & & \\
\hline Strep vestibularis & & & & 口 & & & & & & & \\
\hline
\end{tabular}

$\square=$ Caesarean sample; $\mathbf{\square}=$ vaginal sample level of bacterial contamination in the wound bed. $^{3}{ }^{12-14}$

Any method used for long term tissue preservation must reliably disinfect the stored tissue. Antibiotic disinfection is currently the method of choice for amnion, since this process is thought best to preserve the tissue matrix. However, it is only effective against bacteria, and its effectiveness is dependent on the constituent antibiotics. It is therefore important to assess the degree of preprocessing bacterial contamination, ${ }^{15}$ and to procure the tissue under conditions that minimise contamination.

Virological safety is effected by donor selection and testing for serological markers of infection at the time of donation and 6 months later. ${ }^{16}$ Only on receipt of negative blood test results can the stored tissue be released for grafting.

This study investigates whether there is a reduced risk of bacterial contamination from theatre derived placental membranes. We have identified the contaminants associated with placental membranes retrieved both from caesarean sections and from normal vaginal deliveries.

\section{Materials and methods}

Duplicate samples (approximately $1 \mathrm{~cm}^{2}$ ) of placental membranes from 11 caesarean and 10 normal vaginal deliveries were taken and placed into sterile tryptic soya (aerobic) and thioglycollate (anaerobic) broths. The samples were taken within 10 minutes of delivery. Aseptic technique was used. All instruments, gloves, and the broth bottles were sterile.

The samples were incubated for 1 week at $37^{\circ} \mathrm{C}$. Broths were subcultured into aerobic and anaerobic BacT/Alert bottles. These samples were monitored on the BacT/Alert Microbial Detection System for 14 days. Positive aerobic cultures were then further subcultured onto aerobic and anaerobic blood agar plates and Sabouraud's agar; positive anaerobic cultures were subcultured on to aerobic and anaerobic blood agar. The resulting bacterial colonies were identified using the BBL Crystal Identification System (Becton Dickinson).

\section{Results}

All samples were positive for bacterial contamination. Results of species identification are summarised below (see Table 1). No fungi or yeasts were recovered in either group. A total of 22 different species were recovered. Twelve different species were found on the caesarean samples while 17 were recovered from vaginal deliveries. The number of different species contaminating each sample is shown in Figure 1. The highest number of different contaminants on any one sample was four, found on 


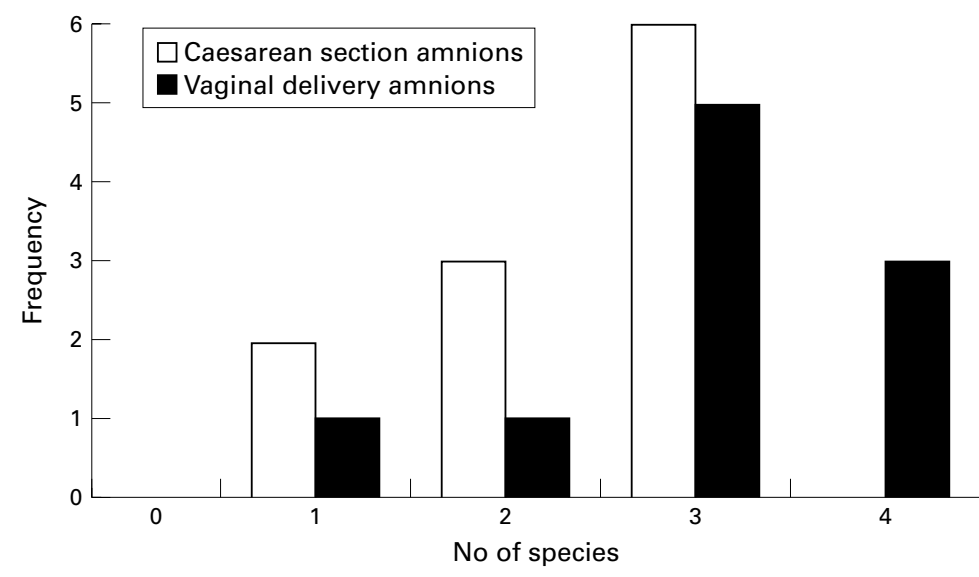

Figure 1 Frequency of numbers of different species recovered.

three vaginal samples. Three different species were isolated on six caesarean and five vaginal samples. The distribution of different species is shown in Table 1. Three species: diphtheroids, Propionibacterium acnes, and Staph epidermidis were found on both caesarean and vaginal samples. The other species isolated reflect the different flora associated with different areas of the body. The average number of contaminating species on each sample was found to be 2.45 on caesarean samples and 3.0 on vaginal samples.

\section{Discussion}

Before any graft can be implanted, it must first be rendered free of bacterial contamination. This requires an effective decontamination process. While antibiotic decontamination is considered to be a suitable method for treating tissue such as heart valves, skin, and amnion it is rendered more effective if two conditions are met. Firstly, it is necessary to establish the likely preprocessing bacterial load, in order not only to identify any pathogenic organisms that might preclude the tissue from clinical use, but also to establish that the antibiotics chosen for decontaminating the grafts are suitable. Secondly, it requires that the tissue be harvested under conditions that minimise the biological burden. These considerations may be of particular significance considering the vulnerability of the cornea to infection from otherwise non-pathogenic species of bacteria.

In this study all the samples collected, both caesarean and vaginal, were contaminated with bacteria. A total of 22 different bacterial species were identified. Samples from caesarean sections had on average fewer species than vaginal deliveries. Twelve different species were recovered from caesareans, while 17 were found on the vaginal delivery samples. Following vaginal deliveries, around $40 \%$ of contaminating bacteria were vaginal or gut organisms, whereas on the caesarean samples, gut and vaginal organisms account for only $10 \%$ of the organisms recovered. In both cases the largest proportion of contaminants were skin organisms.

The most predominant organisms were the common skin commensals, diphtheroids, Staph epidermidis, and Propionibacterium acnes. Diphtheroids were recovered on four caesarean and six vaginal placentas, Staph epidermidis was found on five of both types of delivery, and Propionibacterium acnes was found on eight caesarean and three vaginal samples. Some organisms of pathological significance were recovered. Bacteroides fragilis was recovered from one vaginal delivery sample, and is usually resistant to aminoglycosides, penicillin, colistin, and vancomycin. ${ }^{17}$ Escherichia coli, an occasional pathogen in humans, was found on two samples from vaginal deliveries. Staphylococcus aureus was found on one vaginal sample, as was Shigella $\mathrm{sp}$. No positive species identification of the Shigella was possible, and there remains the possibility that it may have been a misidentified Escherichia coli. Streptococcus gordonii, which was found on one caesarean sample, is a normal mouth commensal, which can cause infective endocarditis if introduced into the blood stream.

While both caesarean and vaginal samples showed contamination by non-pathogenic organisms, the results of this limited comparative study show that both the number of different types of bacteria and the likelihood of contamination by a pathogenic organism are considerably reduced in caesarean deliveries. It is perhaps surprising that all samples from caesarean deliveries were contaminated. This may be a reflection of the radical nature of the procedure, and of the delay between delivery and sampling while theatre staff checked the placenta before the samples were taken.

It might be possible with a more aggressive form of decontamination and suitable postdecontamination monitoring, to collect amnion from vaginal deliveries, giving the benefit of greater availability if large quantities are required for use as a skin substitute. Batch processing might therefore become possible, an important factor in reducing processing costs. However, given the susceptibility of the cornea to infection and the bacteriological findings presented here, we recommend that amnion for use in ocular surgery should be retrieved only from placentas following elective caesarean deliveries.

1 Matthews RN, Faulk WP, Bennett JP. A review of the role of amniotic membranes in surgical practice. Obstet Gynaecol Ann 1982;11:31-58.

2 Trelford JD, Trelford-Sauder M. The amnion in surgery, past and present. Am f Obstet Gynecol 1979;134:833-45.

3 Bose B. Burn wound dressing with human amniotic membrane. Ann Roy Coll Surg Engl 1979;61:444-7.

4 Ninman C, Shoemaker P. Human amniotic membranes for burns. Am f Nurs 1975;75:1468-9.

5 Robson MC, Krizek TJ, Koss N, et al. Amniotic membranes as a temporary wound dressing. Surg Gynaecol Obstet 1973; 136:904-6.

6 Trelford-Sauder M, Trelford JD, Matolo NM. Replacement of the peritoneum with amnion following pelvic exenteration. Surg Gynecol Obstet 1977;145:699-701.

7 Lee SH, Tseng SC. Amniotic membrane transplantation for persistent epithelial defects with ulceration. Am f Ophthalmol 1997;123:303-12.

8 Azuaro-Blanco A, Pillai CT, Dua HS. Amniotic membrane transplantation for ocular surface reconstruction. $\mathrm{Br} f$ Ophthalmol 1999;83:399-402.

9 Prabhasawat P, Barton K, Burkett G, et al. Comparison of conjunctival autografts, amniotic membrane grafts, and primary closure for pterygium excision. Ophthalmology 1997;104:974-85.

10 Shimazaki J, Shinozaki N, Tsubota K. Transplantation of amniotic membrane and limbal autograft for patients with recurrent pterygium associated with symblepharon. $\mathrm{Br} \mathcal{F}$ Ophthalmol 1998;82:235-40.

11 Tseng SCG, Prabhasawat P, Barton K, et al. Amniotic membrane transplantation with or without limbal allografts for corneal surface reconstruction in patients with limbal stem cell deficiency. Arch Ophthalmol 1998;116:431-41. 
12 Colocho G, Graham WP, Greene AE, et al. Human amniotic membrane as a physiological wound dressing. Arch Surg

13 Walker AB, Cooney DR, Allen JE. Use of fresh amnion as a burn dressing. F Paediatr Surg 1977;12:391-5.

14 Robson MC, Krizek TJ. The effect of human amniotic membranes on the bacterial population of infected rat burns. Ann Surg 1973;177:144-9.
15 Thomson PD, Parks DH. Monitoring, banking, and clinical use of amnion as a burn wound dressing. Ann Plastic Surg $1981 ; 7: 354-6$

16 British Association for Tissue Banking. General standards for tissue banking, 1999.

17 Barrow GI, Feltham RKA, eds. Cowan and Steel's manual for the identification of medical bacteria. 3rd ed. Cambridge: Cambridge University Press, 1993. 